\title{
Nostalgia and moral identity: a facilitator model
}

\author{
Jalil Etemaad $^{1}$, Hosein Dabbagh ${ }^{2}$, Bahram Jowkar $^{3}$, Samira Rostami $^{4}$ \\ 1-PhD Candidate of Educational Psychology, Faculty of Education \& Psychology, Shiraz University, Shiraz, Iran \\ (Corresponding Author). ORCID: 0000-0001-9395-0029 \\ 2- Assistant Professor of Philosophy of Ethics and Neuroethics, Tehran Institute of Cognitive Science, Tehran, Iran. \\ ORCID: 0000-0001-9986-2433 \\ 3- Professor, Faculty of Education \& Psychology, Shiraz University, Shiraz, Iran. ORCID:0000-0002-4976-7371 \\ 4- Ph.D. Candidate of Educational Psychology, Faculty of Education \& Psychology, Shiraz University, Shiraz, Iran. \\ ORCID: 0000-0002-9966-8750
}

Received: 30/05/2019

Accepted: 16/07/2019

\section{Abstract}

Introduction: New trend in virtue ethics focuses on personal trait and motivation to highlight the important role of perceptive and motivational aspect of emotions.

Aim: The goal of present research was showed the line to facilitate moral virtues into personal identity by focusing on potentials of nostalgia. The question of the present study is that nostalgia as a non-moral emotion has which relation to the importance of moral virtues.

Method: Method of research was correlational study and $\mathrm{PhD}$ and graduate students of Shiraz University were the statistical society of this research. 71 students participated in this research. Participants responded to event reflection manipulation (Wildschut et al., 2006), Moral identity scale (Aquino \& Reed, 2002) and Nostalgia inventory (Batcho,1995). To analyze of data using SPSS 19, Amos and calculator of composite reliability depend on Raykov s formula (1997).

Results: The result showed that nostalgia was significant positive predictor for internalizing and symbolizing.

Conclusion: The results showed that nostalgia is a positive predictor for internalizing moral values in the individual's self-concept, and also predicting the representation and social pretense as a person who carries some values. Probability, Nostalgia is associated with a kind of emotional regulation and other importance in the person's life, which facilitates the strong moral identity by integration of self and openness to other.

Keywords: Nostalgia, Identity, Moral motivation, Moral psychology

How to cite this article : Etemaad J, Dabbagh H, Jowkar B, Rostami S. Nostalgia and moral identity: a facilitator model. Shenakht Journal of Psychology and Psychiatry. 2019; 6 (4): 110-123 .URL: http://shenakht.muk.ac.ir/article-1-692-fa.pdf

Copyright $\odot 2018$ the Author (s). Published by Kurdistan University of Medical Sciences. This is an open access article distributed under the terms of the Creative Commons Attribution-Non Commercial License 4.0 (CCBY-NC), where it is permissible to download, share, remix, transform, and buildup the work provided it is properly cited. The work cannot be used commercially without permission from the journal. 


\title{
نوستالثى و هويت اخلاقى: يك مدل تسهيلكر
}

\author{
جليل اعتماد'، حسين دباغ ‘ بهرام جو كار ‘ّ سميرا رستمى \\ ا.د كترى روانشناسى تربيتى، دانشكدهى علوم تربيتى و روانشناسى، دانشكاه شيراز، شيراز، ايران (مولف مسئول). ايميل: jetemaad@gmail.com

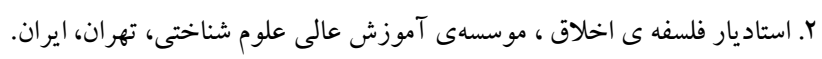

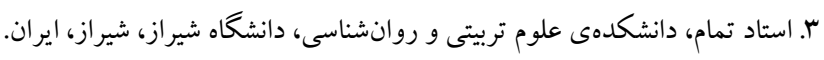

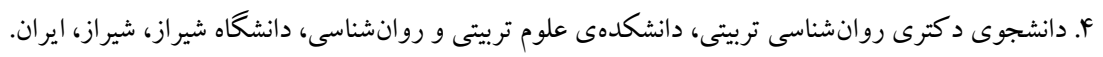

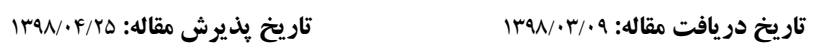

جצאيد

مقده مه: رويكرد نوين فضيلت كرايى اخلاقى، بر خصايص درونى شخص يعنى فضايل و انكيزه ها تمركز

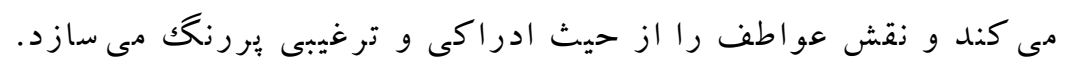
هدف: هدف از يزوهش حاضر يافتن راهى براى تسهيل فضايل اخلاقى در هويت فرد از طريق تمركز بر قابليتهاى هيجان نوستالثى

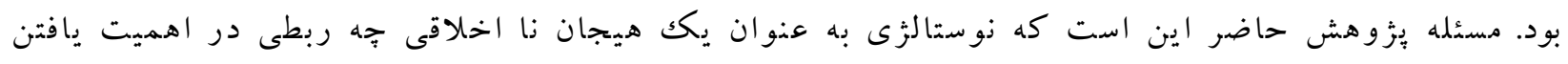
فضا يل هويت اخخلاقى دارد.

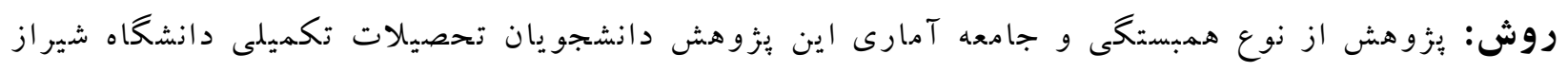

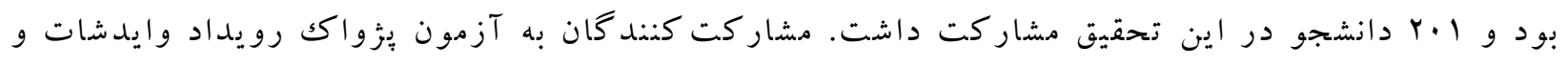

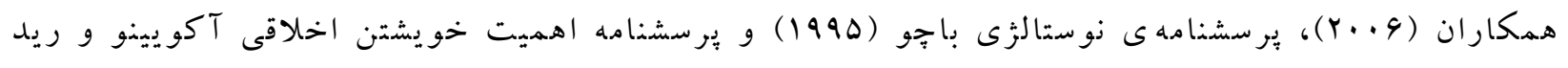

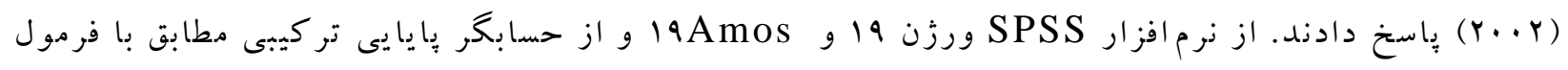

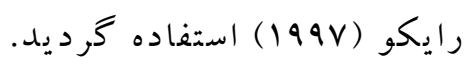

يافته ها: نتا يج نشان داد نوستالزى كرايى بيشبينى كنندهى معنادار هر دو بعد درونى سازى و نمادسازى بود. نتيجه كيرى: مطابق با نتايج به دست آمده، نوستالزى كرايى ييشبينى كنندهى مثبت براى درونىشدن ارزشهاى اخلاقى در

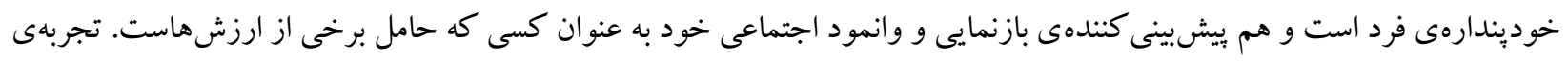

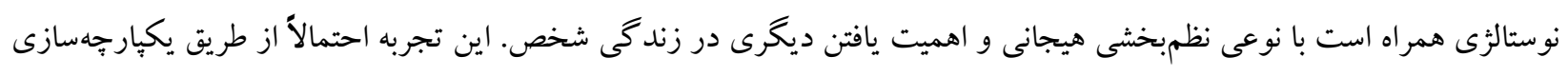

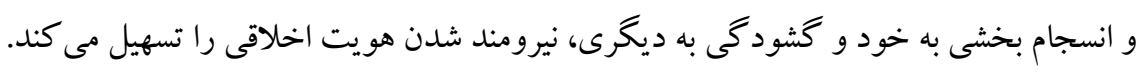
كليد وازهها: نوستالزى، هويت، انخيزش اخلاقى، روان شناسى اخلاق 
سازهى هو يت اخلاقى، يكى از سازه هايى است

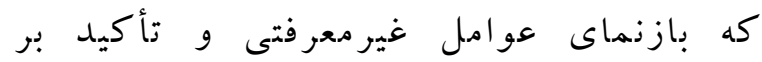
فضايل و انخيزه هاست. مفهوم هويت اخلاقى سازهاى است كه اولين بار توسط بلاسى مطرح شد و خيلى از انديشها بيرامون هويت اخلاقى به مدل (اخوده) بلاسى در بيوند بين قضاوت اخلاقى و عمل بازمى گردد.

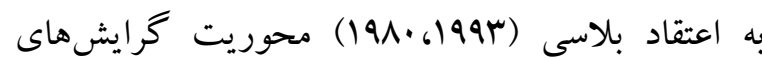
اخلاقى فرد براى برداشت از خود (يعنى هويت اخلاقى) به بهترين وجه، تعهل به رفتار اخلاقى را بيشبينى مى كند. درونى سازى "َ نمادسازى " دو بعد هويت اخلاقى هستند. اين دو بعد هويت اخلاقى، يكى خصوصى و ديخرى

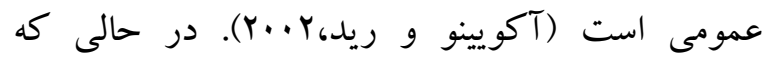
درونىسازى به ميزان اهميت ويز گیىهاى اخلاقى در خوديندارهى فرد مربوط است، (مانند داشتن جنين ويثزى هايى بخش مهمى از وجود مرا تشكيل مىدهد)، نمادسازى مربوط است به نوعى حساسيت فزاينده نسبت به خود اخلاقى به مثابه يكك ابزّى اجتماعى كه در جهان عمل مى كند و خود را مىنماياند (آكويينو و ريد،ب، +.ب). (مانند فعالانه در كارهايى شر كت مى كنم كه داشتن جنين ويزگ گهايى را در من به ديخران منتقل مى كند). درونىسازى نشانگر درجهاى است كه صفات اخلاقى در مركزيت احساس فرد از خودش قرار دارند و نمادسازى نوعى تلاش براى بيانگرى اجتماعى مبنى بر وجود جنين

$$
\text { خصايصى در من است. }
$$

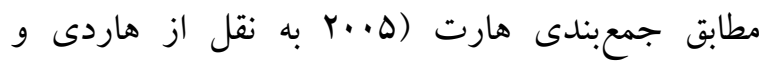

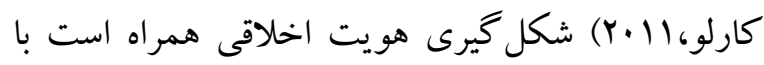

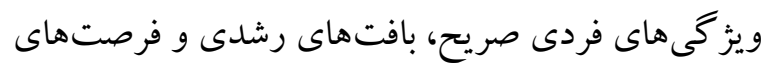
عمل اخلاقى. در زمينهى ويز كىهاى فردى صريح،

3 - Internalization

${ }^{4}$ - Symbolization
مقله

فضيلت كرايان اخلاقى بر فاعل فضيلت مند

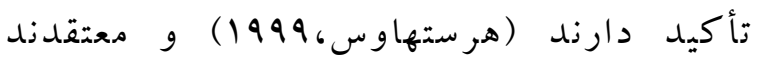
ميان معرفت و عمل اخلاقى عمد تاً كسست

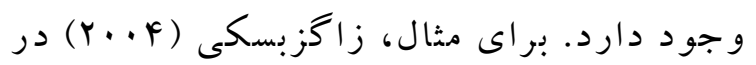
نظر يه خ خود بر خصايص درونى شخص يعنى

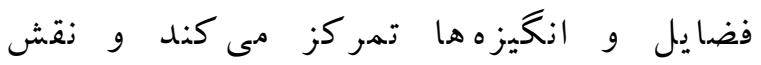
عواطف را از حيث ادراكى و انگيزشى برر زنگ مى سازد. در راستاى خطوط راهنماى فضيلت گرايان جديد، ربط و نسبت هيجانات نا اخلاقى ' در اهميت و اولويت يافتن فضايل در هويت اخلاقى يكى از مسائل برانگيزاننده در حوزهى روانشناسى اخلاق است. الزام اين بررسى از آنجاست كه هويت اخلاقى رابطهاى نيرومند با تعهد فرد به كنشخرى اخلاقى برقرار مىسازد (هاردى و كارلو، ||+r) و لذا تسهيل و نيرومندسازى هويت يافتكى اخلاقى يا درونى شدن فضايل اخلاقى در خوديندارهى فرد به طور غيرمستقيم به كنشخر فضيلت مند و كنشخرى فضيلتمندانه كمك مى كند. به طور مثال، اكر افزايش اهميت بخشايش را به عنوان بخشى از

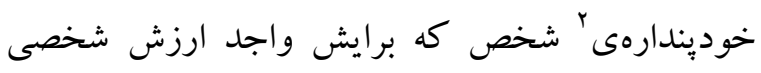

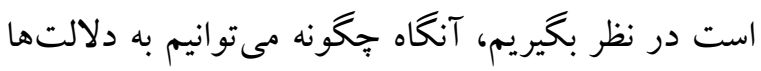

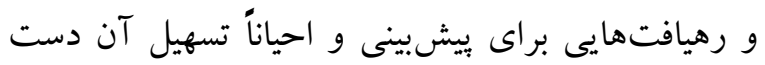
بيابيم؟ اين برسش كانون مسئلهى يُزوهش حاضر است.

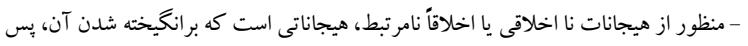

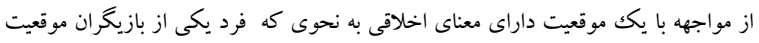

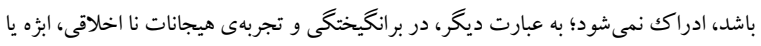

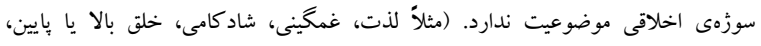

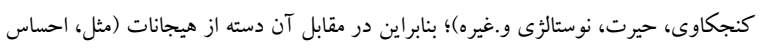

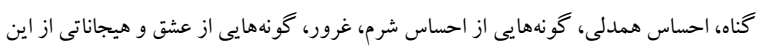

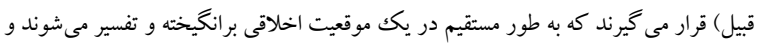
فرد يكى از عاملان موقعيت تلقى مى شود د..

${ }^{2}$ - Self Image 
دىواير و هاوزر، 9.+r) كه وجوه و ابعاد مفهومى و نظرى نسبت هيجانات در اخلاق را مورد تأمّل قرار دادهاند راهخشا به نظر مىرسد. بنا به گزارش هاردى و كارلو (Ylll) نقش هيجانات اخلاقى در شكل گيرى و ييشبينى هويت اخلاقى تائيد شده است و بر اين اساس هيجانات اخلاقى بيش از شكل گيرى هويت اخلاقى به نحوى ابتدايىتر و بس از شكل گيرى هويت اخلاقى و نيرومند شدن آن به نحوى ديخر در فرايند معطوف به كنش اخلاقى نقش ايفا مى كنند اما در مورد نسبت هيجانات نا اخلاقى با هويت اخلاقى به ندرت مطالعهاى صورت كرفته است. در مطالعهى واكر و فريمر (Y..V) نقش هيجانات مثبت (خوشبينى و اميدوارى) و از پِ دشوارى بر آمدن و يادگيرى از دشوارىها به عنوان عوامل مهم در گروه داراى رفتار نوعدوستانه يافته شد. در اينجا اين برسش را به اين صورت باز سازماندهى

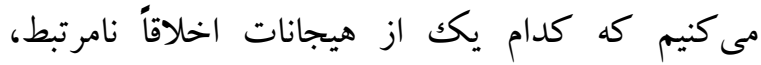
مى توانند بيشبينى كنندهى اهميت و موضوعيت يافتن فضايلى مانند غمخوارى، دلسوزى، عادل بودن، صميميت، بخشايش، يارى گرى، كوشايى، صداقت و ولى مهربانى در خوديندارهى فرد باشد؟ در راستاى باسخ به اين :برسش و با نكاه به بزوهشهاى جديد در زمينهى هيجانات و بهزيستى ( نكاه كنيد به نظمبخشى هيجانى و بهزيستى با وير استارى نيكليك، وينگر هو تس و زيلنبر گك،

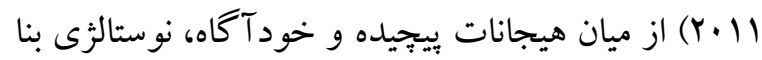
به شواهد بُزوهشى اخيرى كه در مورد آن وجود دارد كانديد قابل توجهى به نظر مىرسد. بنابراين فهم اين نكته كه نوستالزى گرايى احتمالاً در تعليم و تربيت اخلاقى جهـ نقشى دارد و احياناً مربّيان و روانشناسان اخلاق جِّونه مى توانند از يتانسيل هاى اين هيجان در غنى كردن رشد و
داشتن بيشرفت تحصيلى ييشبين مثبت هويت اخلاقى است (هارت، اتكين و فورد، 1999 به نقل از هاردى و كارلو،|(Y). (Y). در مطالعهى واكر و فريمر (Y...P) عامليت شخصى، وييوند با ديخران، دلبستكى دوران كودكى به مراقبها، هيجانات مثبت (خوشبينى و اميدوارى) و از بس دشوارى بر آمدن و ياد گيرى از دشوارىها به عنوان عوامل مهم در كروهى از افراد كه واكنشهاى نوعدوستانه داشتند ديده شده است. در زمينهى بافت رشدى، گرمى والدين از جمله متغيرهاى است كه بيوند مثتى با درونىسازى بيشتر ارزشهاى اخلاقى نشان

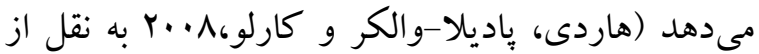

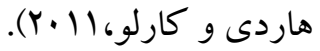
به اعتقاد والكر و و فريمر (Y.V. ما نيازمند فهم نقش تعاملات ميان متغيرهاى فردى و موقعيتى در حيطهى يثزوهشهاى اخلاق هستيم. هاردى و كارلو (11) بس از مرور نظرى و تحقيقات تجربى ييرامون هويت اخلاقى، محدوديت تحقيقات قبلى را شامل دانش كم در مورد بنيادهاى نورولوزيكى هويت اخلاقى، مسئلهى ثبات آن در خلال موقعيتها و زمان و دانش كم در مورد اينكه جطور شناختهاى اخلاقى، هيجانات (همدلى و احساس كناه) و تأثيرات فرهنگى در نسبت با هم در شكل گيرى يا بيشبينى هويت اخلاقى نقش ايفا مى كنند، مى دانند. با اين جارجوب، رجوع به هيجانات بيّيديده كه دلالتى براى تسهيل اهميت يافتن فضايل در خوديندارهى فرد داشته باشند يكك كام بثزوهشى عمده و رو به جلو در راستاى رسيدن به رهيافتهايى براى تربيت اخلاقى

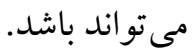
براى فهم نقش هيجانات در اخلاق و متعاقباً هويت اخلاقى، توجه به كارهاى برخى بُزوهشخران (هيوبنر، 


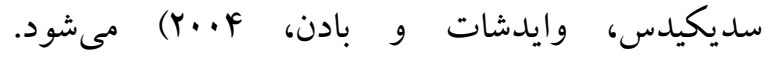

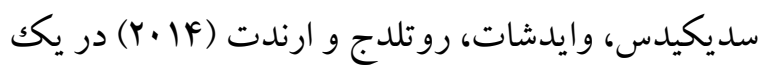
سرى تحقيقات آزمايشى نشان دادند كه نوستالثى به مثابه پاسخى است براى عدم انسجام خود و منبعى است براى انسجام خود. يافتهاى اين محققان بر نقش نوستالزى در تغييرات بين انسجام خود و عدم انسجام خود و بر نقش همافز ايندهى نوستالزى براى عزت نفس دلالت داشت. در تحقيقى ديخر نقش نوستالزى به عنوان مكانيسمى كه فعال كننده و تسهيل كنندهى انسجام است و بين خود، كذشته و حال بيوند برقرار مى كند مورد تائيد قرار گرفت

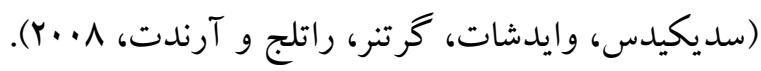
از منظرى اجتماعى و بينفردى، جنگگك، سديكيدس و و وايدشات (Y) (Y) با انجام جند تحقيق آزمايشى نشان دادند نوستالزى از طريق افزايش بيوند اجتماعى (احساس يذيرش و تعلق يذيرى) يرورش دهندهى خوشبينى است. وجه اجتماعى تجربهى نوستالزى از جمله در ظرفيت اين هيجان براى ترغيب حمايت اجتماعى و دوستانه، تغذيهى

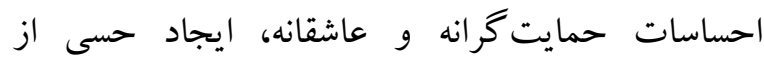
شايستگى بينفردى، ترغيب رفتار جامعه يسند (به طور مثال داوطلبى و بخشش بيشتر براى امور خيريه، داوطلبى

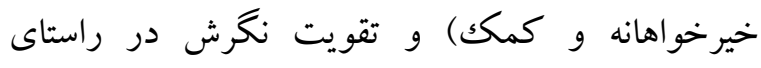

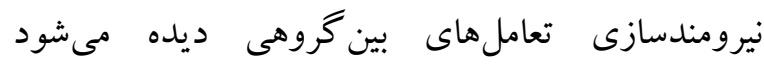

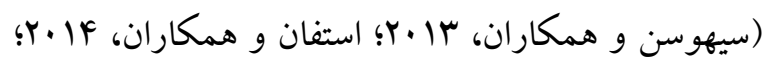
ترنر، وايدشات و سديكيدس، rإ.ب؛ ترنر، وايدشات، سديكيدس و كئور گيو، با.ب؟؛ وايدشات و همكاران،

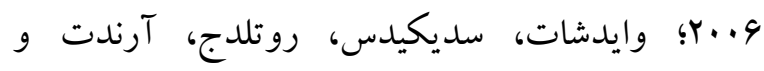

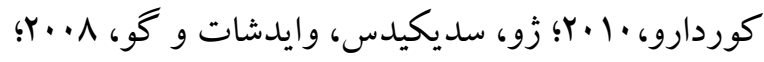

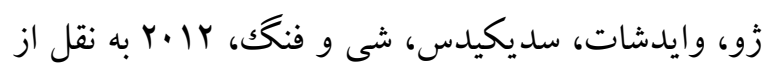

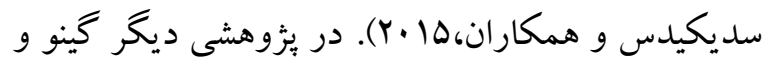

انخيزشهاى اخلاقى كمك بخيرند، از دستاوردهاى يزٔوهش حاضر است. مطابق با جديدترين رويكرد به نوستالزى كه حاصل مفهومسازى و ئزوهشهاى دههى نود ميلادى به اين سو

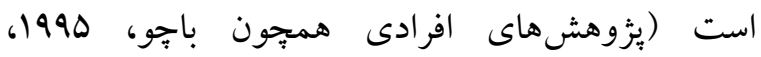

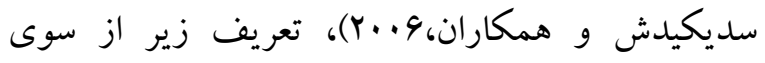
يثزوهش ما استخراج و ارائه مى گردد. نوستالزى هيجانى وابسته به خود، فردى-اجتماعى كه داراى ماهيت دو كانهى غمخينى -شادمانى توأم است و همراه با نوعى بـى آرزومندى نسبت به كذشته كه توسط يكى شبكهى عاطفى فراخوانى شده ناشى از يك محرك بيرونى به طور فعال يا منفعل تجربه زمان حال را به تجربهى خاطرات كذشته بيوند مىزند (اعتماد، جو كار، دباغ،

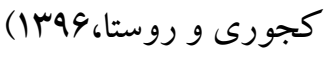
محققان معتقدند نوستالزى مى تواند يك حس نيرومند دربارهى خود را برانگيزد و وحدت درونى خود را از

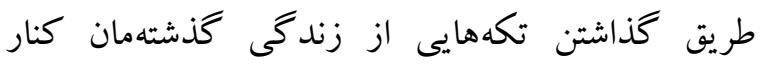
يكديكر افزايش دهد (سديكيدس، وايدشات و و ونى

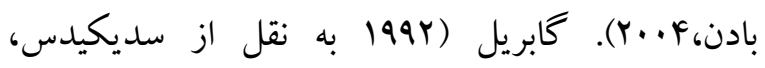

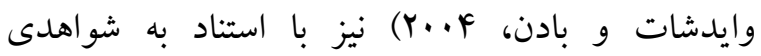
نوستالثى را در راستاى تقويت هويت و ارزشمندى خود مى داند. نوستالزى به بيوندهاى اجتماعى استحكام و نيرو

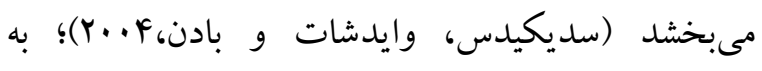
عبارت ديخر نوستالزى همراه است با نوعى بازسازى

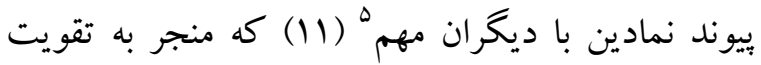
بيوند اجتماعى، عزت نفس (سيرى و باوميستر، .... بـ به

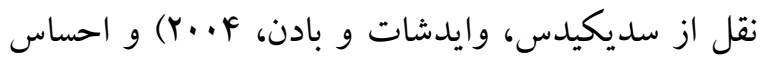

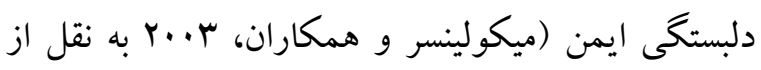

\footnotetext{
5- Significant others
} 
مرور تحقيقات انجام گرفته نشان داد كه تاكنون محققان نقش نوستالزى را در راستاى تسهيل موضوعيت يافتن فضايل اخلاقى در خوديندارهى فرد و بيشبينى هويت اخلاقى مورد يرسش و بررسى تجربى قرار ندادهاند و اين يخزوهش با طرح اين مسئله در راستاى يافتن راهى به سمت تسهيل هويت اخلاقى در يكك افق فضيلت گر ايانه، با بيوند دادن روند يُزوهشهاى مربوط به بيشايندهاى هويت اخلاقى و ييامدهاى نوستالثزى، مسئلهاى بيرامون اين دو متغيّر را در نسبت با يكديخر مورد بررسى قرار داده و مدل مفهومى زير راصورتبندى كرده است.
دساى (Y. Y. (Y) نشان مىدهند افرادى كه حافظهى كودكىشان را فراخوانى كردند، نوعى احساس خلوص اخلاقى از خود نشان دادند (هم آكاهانه و هم ناخود آكاهانه) و به طور جامعه يسندترى با ديخران رفتار كردند. اين محققان نتيجه گرفتند كه يادآورى حافظهى دوران كودكى مىتواند به تسهيل كمكك به ديخران و ديخر سنخهاى رفتار معطوف به ديخرى بيانجامد. در همين راستا به صورت صريحتر نقش نوستالثى در كنش لث له همدلانه و نوعدوستانه در يك تحقيق آزمايشى توسط اعتماد، جو كار، حسينجارى و دباغ (زيرجاب) مورد تاييد

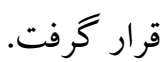

شكل 1 مدل مفهومى يزؤهش

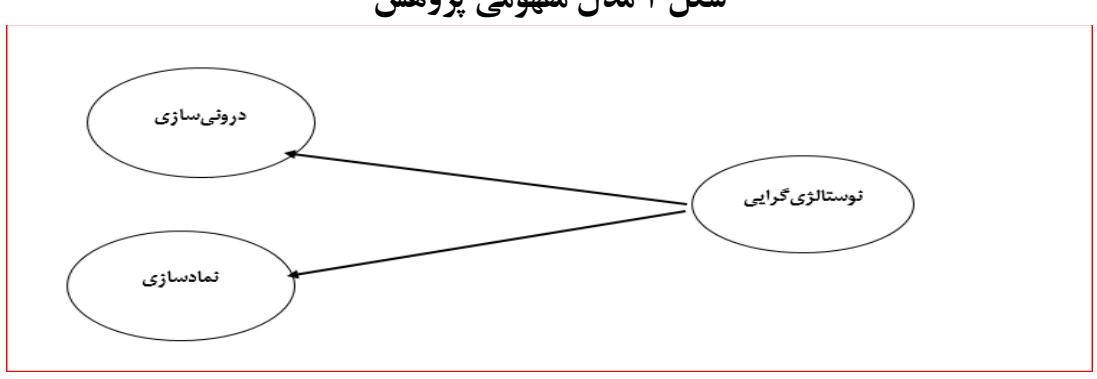

به تحصيل بودند و بهصورت در دسترس انتخاب شدند. روش معيار ورود مشاركت كننده عبارت بود از دانشجوى يثزوهش حاضر از نوع همبستكى بود و در قالب يك مدل

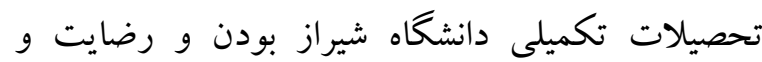
روابط متغيرهاى برونزاد (نوستالزى گرايى) و درونزاد تمايل شخصى به مشاركت. ابزارهايى كه ناقص تكميل (ابعاد هويت اخلاقى -درونى سازى و نمادسازى-) را مورد شده بود و يا ويز كىهاى معيار ورود را نداشت كنار كذاشته شد. مبناى تعيين حجم نمونه بر اساس تعداد گويه اين مقياس تعيين شد كه برابر ملاكك ييشنهاد شده در منابع

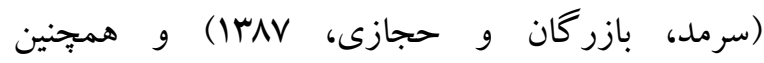
كلاين،199F به نقل از حبيبيور و صفرى، بـMM|) بوده است. اين گروه به شيوه نمونه گيرى در دسترس انتخاب شدند. به اين ترتيب كه به درب اتاقها در خوابكاههاى

$$
\text { بررسى قرار داد. }
$$

جامعهى در دسترس اين بثزوهش دانشجويان تحصيلات تكميلى دانشگاه شيراز و جامعلى نهايى دانشجويان تحصيلات تكميلى دانشخاههاى دولتى ايران هستند.

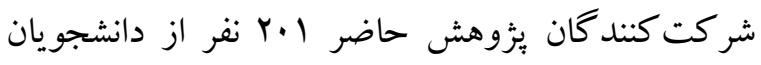
تحصيلات تكميلى رشتهاى مختلف ساكن خوابگاههاى دانشگاه شيراز بودند كه در سال تحصيلى هذ-99 مشغول 
بر روى كاركران جينى، ضريب همبستكى أ|/ را بين

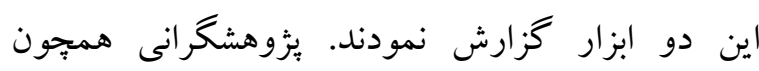
ويدسشات و همكاران (4. . (Y) عنوان كردهاند كه با توجه به جندبعدى بودن تجربهى نوستالزى و اينكه اين ابزار تنها مو اد نوستالزيكك و عمق اين تجربه را مىتواند بسنجد و نه

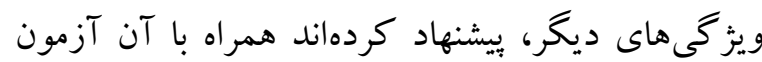
وارسى دست كارى ويدسشات و همكاران نيز اجرا گردد. مقياس هويت اخلاقى (MI): : برسشنامه هويتاخلاقى مقياس خود گزارشدهى است كه به وسيله آكويينو و ريد (Y.... ساخته و اعتباريابى شده و داراى دو زير مقياس درونى سازى (ميزانى كه هويت اخلاقى در خودينداره فرد مركزيت يافته) و نمادسازى (ميزانى كه هر آزمودنى هويت اخلاقى را در ظاهرش نشان مىدهد) است. در ابتدا از افراد خواسته مىشود كه به صفات اخلاقى كه در بالاى برسشنامه نوشته شده توجه كنند. صفاتى جون مهربان، عادل، زحمت كش و ... يس از آن ده سؤال

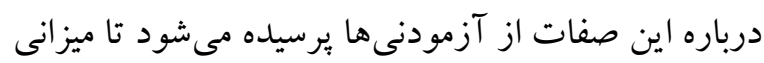
كه داشتن اين صفات براى فرد مهم است، تعيين شود. ياسخدهى در طيفى از يكك (كاملاً مخالفم) تا ينج (كاملاً موافقم) در هر يكك از ده سؤال گسترده شده است. نمره كذارى دو كويه F و V لبه صورت معكوس صورت مى كيرد. در مطالعهى آكويينو و ريد (Y...Y) ضمن بررسى رابطه درونى سازى و نمادسازى با سازههاى همگن و سازهاى متمايز، نشان دادند كه نتايج روايى همخرا و و واكراى اين دو سازه رضايتبخش است. همجِنين،

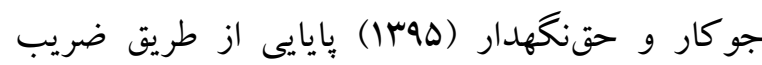

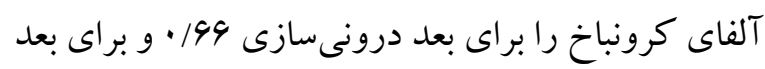

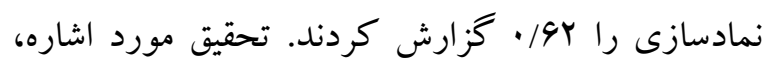
شواهد مثبى براى روايى ابزار نيز ارائه داده است.
دختران و يسران مراجعه و از دانشجويان كارشناسى ارشد و دكترى حاضر در اتاق درخواست شد كه مقياسها را تكميل كنند. ميانكين سن دانشجويان

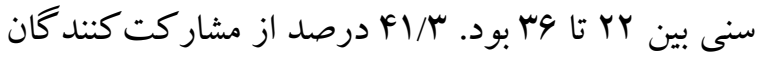
زن و ه/N/V درصد زن بودند. س/اس درصد دانشجوى دكترى و 9V/A درصد دانشجوى كارشناسى ارشد و F درصد نيز دانشجويان سال آخر ليسانس بودند كه براى امتحان كارشناسى ارشد آماده مىشدند. وضعيت شغلى .

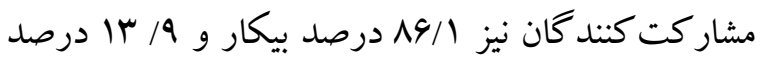

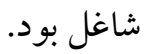

ابزار يرسشناملى نوستالثى باجو (1990): اين مقياس توسط باجِو (1990) ساخته شده است. باسخگگ بان بايد ميزان

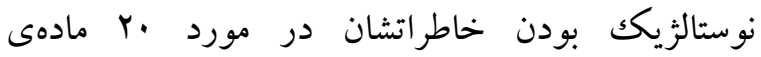
فراخوانى كننده، در يك طيف 9 درجهاى از هر كز تا بسيار زياد را مشخص كنند. اين آيتمها شامل مواردى

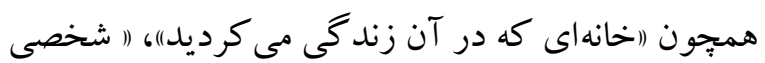
كه دوست داشتيد)، (ا نداشتن نكرانى" و ...غيره است كه از فرد خواسته مىشود ميزان احساس فقدان و خواستن اين موارد را با توجه به كذشتهاش مشخص كند. در مطالعهى باجيو (1991، 1990) شواهدى مبنى بر روايى مقدماتى اين ابزار ارائه شده است و بايايى آن در دو

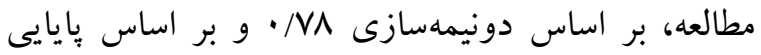
باز آزمايى AF/ توسط اين تحقيق گزارش شده است. ميزان آلفاى كرونباخ مبنى بر بايايى آن در بثروهش سديكيدس

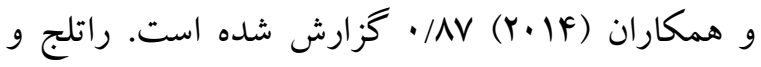

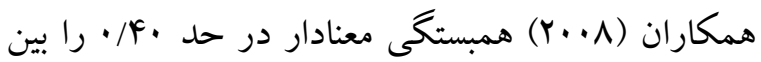
نمرهى اين ابزار با نمرهى مقياس نوستالزى ساوتهميتون

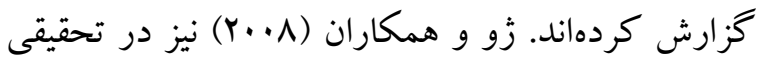


توصيفى مشاركت كنند گان در جداول ا آورده شده

يافتهها

است. شاخصهاى توصيفى شامل ميانگين و انحراف

نتايج در دو بخش توصيفى و رگرسيون گزارش

معيار متغيرهاى مورد بزّوهش به تفكيك جنسيت مورد مى گردد. به منظور ارائه تصويرى آشكار از وضعيت بررسى قرار كرفت كه نتايج در جدول شماره ا آمده عملكرد مشار كت كنند كان در متغيرهاى بزّوهش، ابتدا است. همانطور كه مشاهده مىشود ميانگين دختران در يافته هاى توصيفى و همبستخى (مرتبه صفر) بين متغيرهاى متغير بيش بين بئوهش بيشتر از يسران است و اما ميانگين يثزوهش محاسبه گرديد (جدول). يافته هاى به دست آمده دختران و يسر ان در متغيرهاى ملاكك برابر بودند.

كوياى آن است كه بين متغيرهاى مستقل و وابسته رابطه معنادارى وجود دارد كه مجوز لازم براى انجام تحليل هاى بعدى را فراهم مى آورد. برخى از مشخصات

\begin{tabular}{|c|c|c|c|}
\hline \multirow[b]{2}{*}{ ميانكين كل } & \multicolumn{2}{|c|}{ ميانكين و انحر اف استاندارد } & \multirow[b]{2}{*}{ متغيرها } \\
\hline & 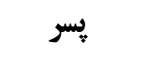 & دختر lخت & \\
\hline$(r \cdot / 9 V) 1 \cdot r / 9 Y$ & $(Y \Lambda / r) q V / \cdot \Gamma$ & $(r / / 9) 1 \cdot V / \cdot \Delta$ & نوستالزى كرايى \\
\hline$(r / Y \varphi) r \cdot / r V$ & $(r / F q) r \cdot / \varepsilon q$ & $(r / I r) r \cdot / l 1$ & هويت اخلاقى درونى \\
\hline$(r / V \cdot)|F| q$ & $(r / F \Gamma) \backslash 9 / \cdot \Lambda$ & $(\curlyvee / \wedge 9) \backslash 9 / 1 \wedge$ & هويت اخلاقى نمادسازى \\
\hline
\end{tabular}

به منظور بررسى ارتباط بين متغيرها همبستخى صفر مرتبه مشاهده مى شود متغيرهاى بزوهش رابطه معنىدار بين تمام متغيرهاى يزوهش محاسبه شد. نتايج ماتريس

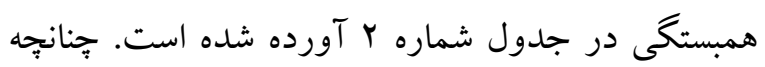

جدول r ماتر يس همبستغى متغير هاى يزوهش

\begin{tabular}{|c|c|c|c|c|}
\hline \multirow[t]{4}{*}{$p$} & $r$ & $r$ & 1 & متغيرها \\
\hline & & & 1 & 1-نوستالزى \\
\hline & & 1 & $\cdot / 19_{*}^{*}$ & r-هويت اخلاقى درونى سازى \\
\hline & 1 & 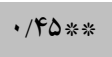 & $\cdot / r \Delta \%$ & ז-هويت اخلاقى نمادسازى \\
\hline
\end{tabular}

جدول r نتايج مربوط به روايع و بايايى مدل هاى اندازه تيرى تحقيق

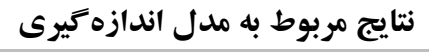

عامل




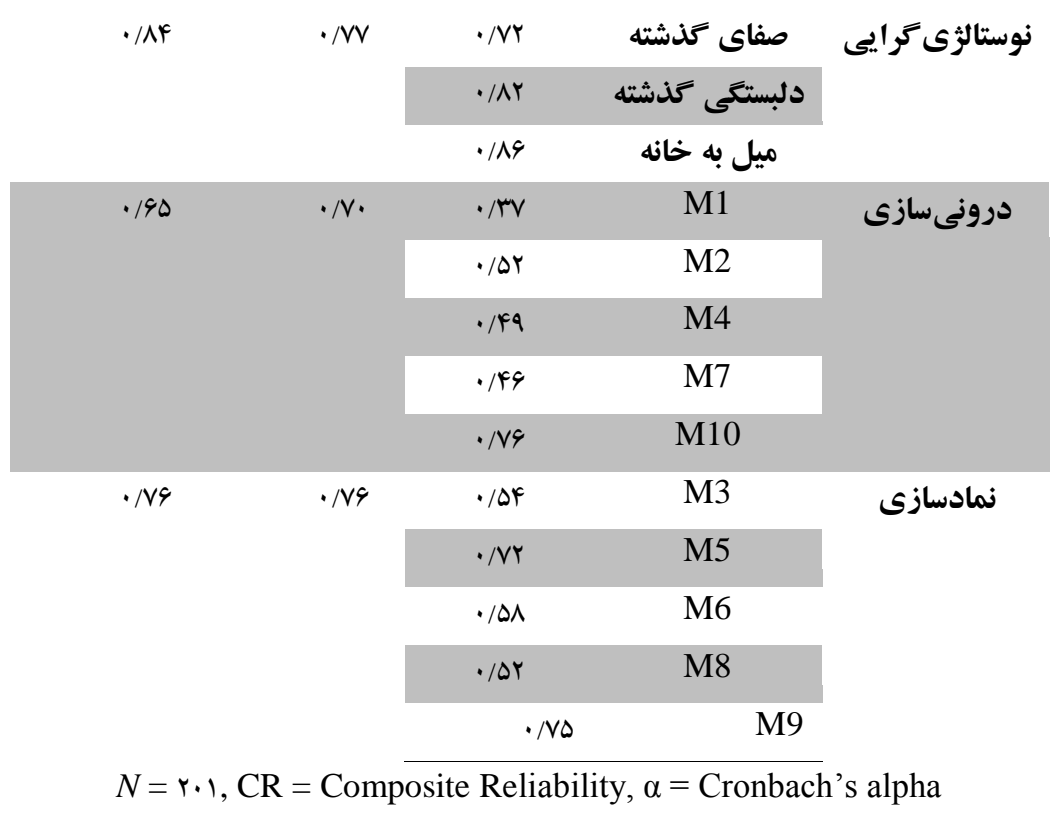

مطابق با نتايج جدولها، شاهد بايايى و پيايايى تركيبى مدلهاى اندازهگيرى سازههاى تحقيق هستيم. در ادامه مدل نهايى يزوهش آورده شده است.

\begin{tabular}{|c|c|c|c|c|c|c|c|c|}
\hline TLI & CFI & IFI & AGFI & GFI & RMSEA & p.value & $x^{2} / \mathrm{df}$ & مدل \\
\hline.$/ 99$ & $\cdot / 9 V$ & $\cdot / 9 V$ &.$/ 9 Y$ &.$/ 9 F$ &.$/ \cdot F$ &.$/ 4$ & $1 / \pi T$ & مدل آزمون شده يزووهش \\
\hline
\end{tabular}

مطابق با نتايج شكل ا و جدول F، شاهد برازش مطلوب مسيرهاى ميان متغيرهاى مكنون در بازهى مطلوبى قرار مدل تجربى تحقيق هستيم. ضرايب مربوط به نسبت دارد كه نشاندهندهى نقش نوستالزى گرايى در تبيين ابعاد

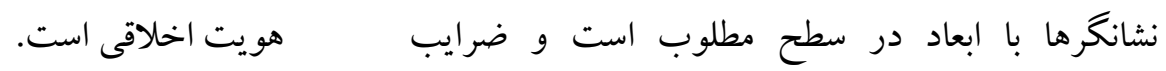


شكل r مدل ساختارى بزوهش

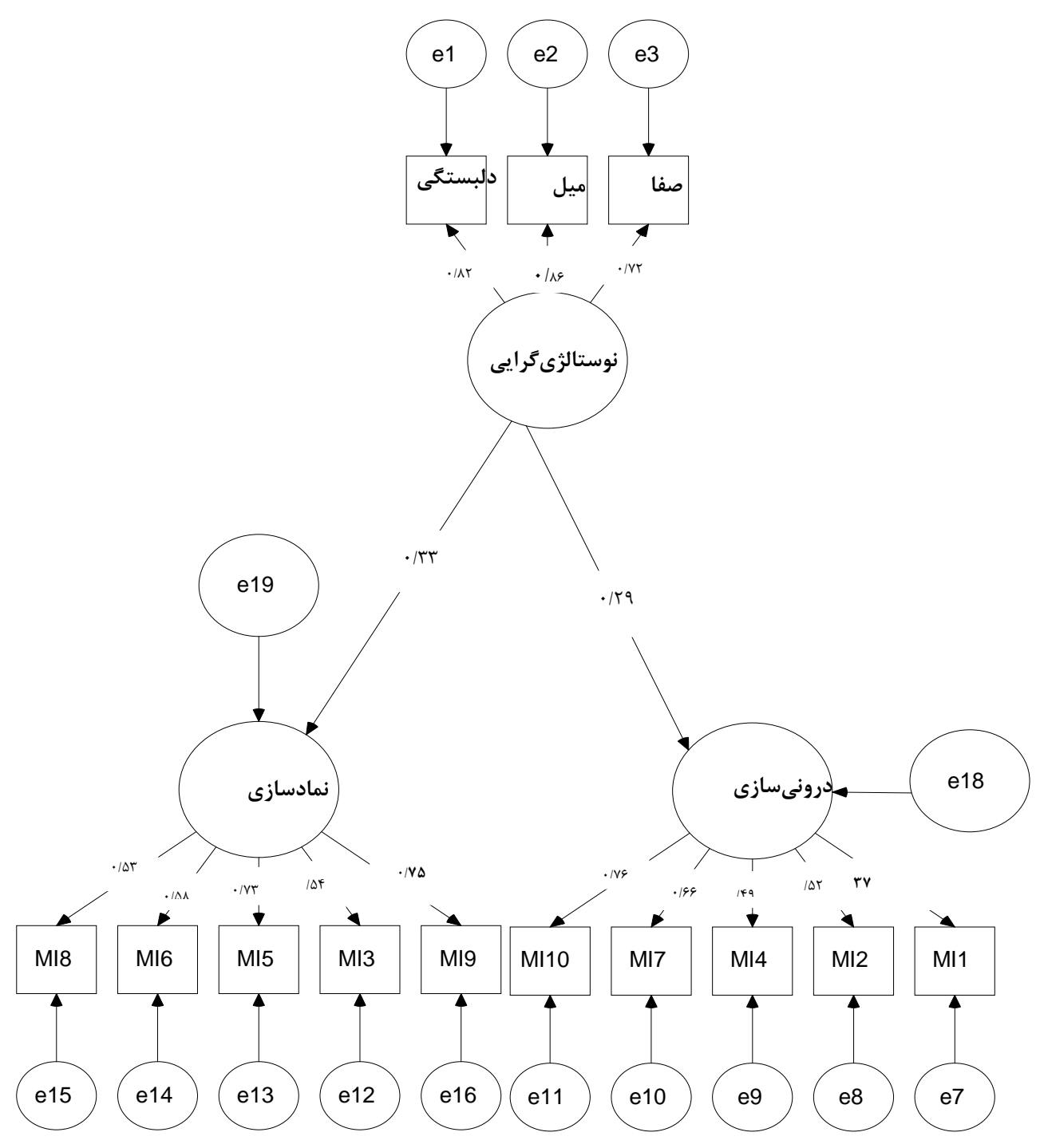

درونىشدن ارزشهاى اخلاقى در خوديندارهى فرد است

و هم بيشبينى كنندهى بازنمايى و وانمود اجتماعى خود

$$
\text { به عنوان كسى كه حامل برخى از ارزشهاست. }
$$

در زمينهى نقش معنى دار نوستالزى گرايى در ابعاد هويت

اخلاقى اكر جهه تحقيقات جندانى صورت نخر فته است، امّا

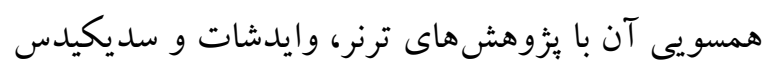

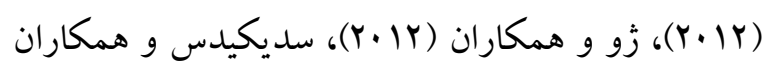

نتايج آزمون فرضيه نشان داد، فرضيهى تحقيق مبنى بر مدل تسهيل كنندهى هويت اخلاقى تائيد مى شود؛ بنابراين نوستالزى گرايى مىتواند بيشبينى كننده و به به احياناً تسهيل كنندهى هويت اخلاقى باشد و بخشى از واريانس هر دو بعد نمادسازى و درونىسازى را تبين كند.

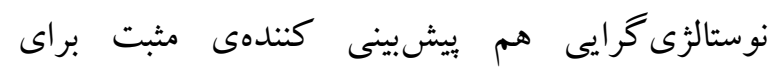


كنش همدلانه و نوعدوستانه با نتايج تحقيق حاضر همسويىهايى دارد. جِنان كه ملاحظه شد، تحقيقات آورده شده به عنوان همسو، يا اشاره به نقش نوستالزى در

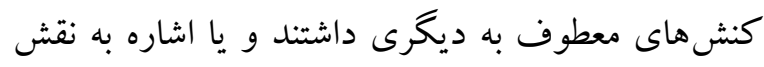
نوستالزى در هويت و انسجام خود كه در هر صورت با تحقيق حاضر واجد نوعى همسويى مىشوند. در اين زمينه، تحقيق نظرى و غيرتجربى لى (ها ·Y) كه نشان دهندهى نقش نوستالزى در ترغيب رفتارهاى جامعهيسند و نوعدوستانه است تلويحاً همسو با نتايج تحقيق حاضر است. مطابق با مكانيسم بيشنهادى لى

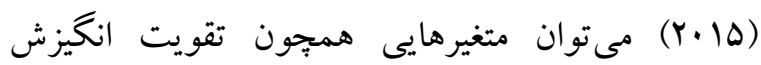
كر ايشى و تقويت هويت اجتماعى و احساس همدلى را به عنوان مكانيسم زيرين تسهيل كنندهى نقش نوستالزى در كنش همدلانه و متعاقباً اهميت يافتن همدلى در هويت اخلاقى در نظر گرفت. جֶنان كه كفته شد تحقيق لى

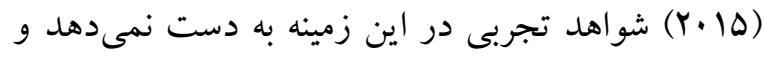
مبتنى بر تحقيقات قبلى و تلويحات نظرى و قياسى رهيافتهاى خود را ارائه مىدهد. در تائيد مكانيسم بيشنهادى لى (10) تحقيق سديكيدس، وايدشات و و بادن (Y...... مبنى بر تائيد نقش نوستالزى در بازسازى ييوند نمادين با ديخران و افزايش وحدت درونى قابل تأمّل است؛ بنابراين بر اساس خطوط راهنماى لى (ها بـ (Y)، نوستالزيك شدن به تسهيل انخيزش كرايشى و تقويت هويت اجتماعى و عواطف همدلانه مىانجامد. در همين راستا، مىتوان به يافتهى جنَك، سديكيدس و وايدشات

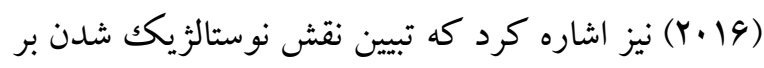
افزايش خوشبينى را مبتنى بر اين دانستند كه احساس

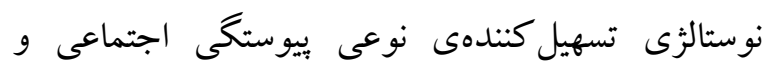
عزت نفس است و از اين طريق به افزايش خوشبينى در
(Y.|F) براى كاركردهاى اجتماعى، گروهى و ارتباطى نوستالزى همجِون تمايل به رفتار جامعهِّند و رفتار همكاران را نشان دادهاند نزديكك است. تحقيق جوردن، مولن و

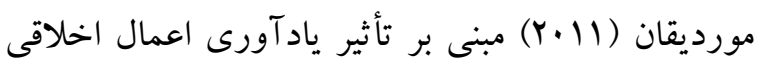
كذشته در رفتارهاى اخلاقى آينده نيز تلويحاتى در بادي همسويى با يافتهى اين تحقيق داراست. در اين زمينه همجنين تحقيق كاوانا (1919 به نقل از سديكيدس، وايدشات و بادن، F .... كه شواهدى نشان داد مبنى بر اينكه نوستالزى به عنوان منبع دستيابى به هويت عمل

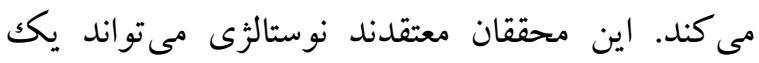

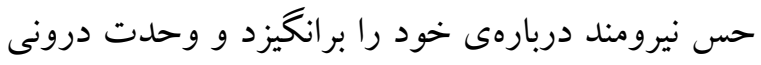

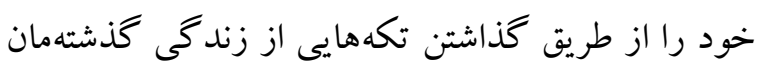
كنار يكديخر افزايش دهد. كابريل (1999 به نقل از

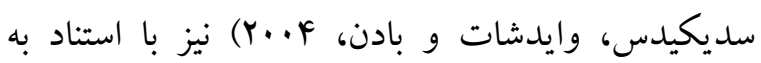
شواهدى نوستالثى را در راستاى تقويت هويت و ارزشمندى خود مىداند. همسويى ميان اين يافته با اينكه نوستالزى به بيوندهاى اجتماعى استحكام و نيرو مىبخشد (سديكيدس، وايدشات و بادن، F) (Y. نيز قابل تأمّل است. به عبارت ديخر نوستالثى همراه است با نوعى بازسازى

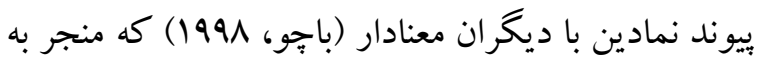
تقويت بيوند اجتماعى، عزت نفس (سيرى و باوميستر،

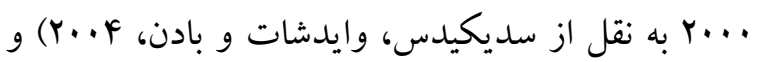
احساس دلبستخى ايمن (ميكولينسر و همكاران، ب... ب. به

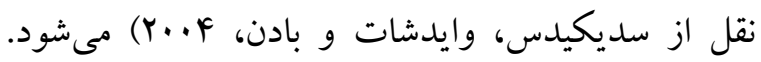

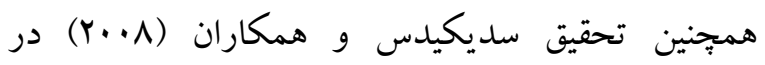
زمينهى نقش نوستالزى در تسهيل انسجام خود با نتايج تحقيق حاضر همسو است. افزون بر اين تحقيق اعتماد همكاران (زيرجاٍ) در زمينهى نقش نوستالثى در تسهيل 
گرايشى، افزايش حس وييوستكى بينفردى و اجتماعى

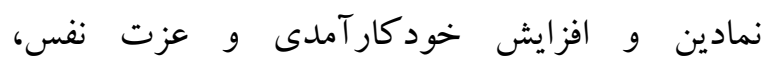
نيرومندسازى هويت و انسجام خود، وحدت درونى و ارزش خود و تسهيل بازسازى بيوند نمادين با ديخران معنادار كه در بيشينه مورد تائيد قرار گرفته است، مىتى بواند به عنوان بيشبينى كننده و و احياناً تسهيل كنندهى قدرتمندى درونىسازى و نمادسازى خودينداره اخلاقى مطرح باشد. اين يافته نقش نوستالزى را به عنوان يك تسهيل كنندهى قدرتمندى خوديندارهى اخلاقى قابل بررسى مىسازد. بنابراين از منظر مسئلهى بثزوهش حاضر، نقش نوستالزى گرايى در بيشبيشى و و احياناً تسهيل

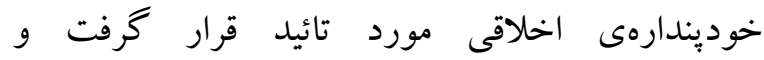
بثزوهشهاى روانشناسى اخلاق با يكك مسئلهى تازه با عنوان نظمبخشى هويت اخلاقى از طريق نوستالزى گرايى روبهرو هستند كه مىتواند براى بيشبرد مسائل انضمامى مورد توجّه قرار گيرد. اين يافته در بنيادى ترين شكل خود در بستر رويكرد فضيلت گرايى اخلاقى و اهميت نقش ئش متغيرهاى غيرشناختارى فاعل اخلاقى قرار مى گيرد و

$$
\text { فهميده مىشود. }
$$

محدوديتهاى اين تحقيق از زمله محدوديتهايى است كه بر يكك طرح همبستخى وارد است. در اين تحقيق نقش نوستالثى به عنوان يكك ييشبينى كننده و احياناً تسهيل گر هويت اخلاقى روشن شد. البته براى نتيجه گيرى شفافتر نيازمند تحقيقات

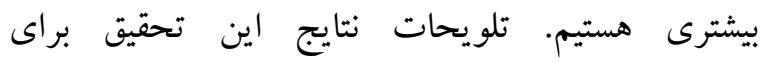
روانشناسى و تربيت اخلاقى جنان كه كفته شد داراى اهميت قابل ملاحظهاى هست.
روابط اجتماعى منجر مى گردد. اين يافته در يرتو فرضيهى بدنمندى نوستالزى نيز قابل بازفهمى است، مطابق با اين فرضيه تجربهى نوستالزى همراه و متوقف است بر تغييرات بدنى و نوروفيزيولوزيكى؛ به عبارت ديخر توجه به نقش بدن و بدنبنياد بودن تجربهى نوستالزى از اين طريق كه نوعى تغيير خلق مثبت و تسهيل

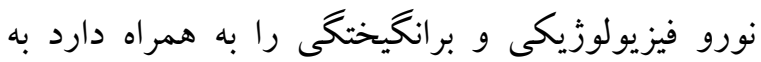
لحاظ نظرى داراى اهميت است. در اين راستا تحقيق اعتماد و همكاران (941) نقش نوستالثى را به عنوان يكك مكانيسم نظمبخشى هيجانى كه بر نقش محورى حافظه مبتنى است مورد تائيد قرار دادند و نشان دادند كه اين هيجان مىتواند با راهاندازى يكك شبكهى عاطفى،

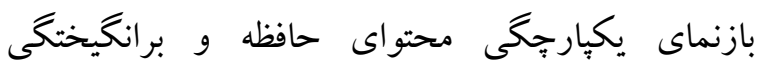
نوروفيزيولوزيكك باشد. تبيينهاى مورد نظر بر اساس بـاس بـاس

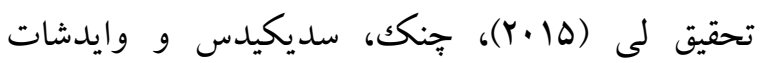
(Y.19)، جوردن، مولن و مورديقان (Y) (Y) و اعتماد و همكاران (494) در يك محور مشتر كك هستند كه نشان مىدهند تجربهى نوستالزى همر اه است با نوعى نظمبخشى هيجانى و انسجام بخشى كه با يكيارجهه سازى ظرفيتهاى بلنى و شناختى از طريق هيجان، انجام كنشهاى اجتماعى و ديخر -محور را تسهيل مى كند. از منظر

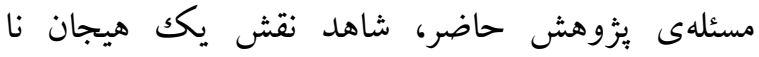
اخلاقى در تسهيل قدرت خوديندارهى اخلاقى هستيم.

\section{نتيجه كيرى}

تحقيق حاضر در راستاى مسئلهى نسبت يكك هيجان اخلاقاً نامرتبط با تسهيل شدن قدرتمندى خوديندارهى اخلاقى مطرح شد. نتايج نشان داد نوستالثى گرايى از

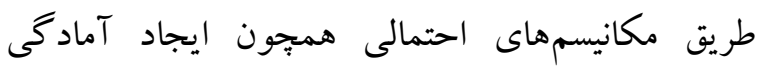
حسى -حركتى و نوروفيزيولوزيكى، افزايش انگيزش 
Gino F, \& Desai S. (2012). "Memory Lane and Morality: How Childhood Memories Promote Prosocial Behavior." Joumal of Personality and Social Psychology 102(4), 743-758.

Haidt J. (2003). The moral emotions. IN: R. J. Davidson, K. R. Scherer, \& H. H. Goldsmith Editors.,Handbook of affective sciences. Oxford: Oxford University Press,852-870.

Hardy S, \& Carlo G. (2011). Moral Identity: What Is It, How Does It Develop, and Is It Linked to Moral Action?. Child Development Perspectives, 5 (3), 212-218.

Hardy SA. (2006). Identity, reasoning, and emotion: An empirical comparison of three sources of moral motivation. Motivation and Emotion, $30(3), 207-215$.

Hoffman ML. (2000). Empathy and moral development: Implications for caring and justice. New York: Cambridge University Press.

Huebner B, Dwyer S, \& Hauser MD. (2009). The role of emotion in moral psychology. Trends in Cognitive Science, 13(1), 1-6.

Hursthouse R. (1999). On Virtue Ethics. Oxford: Oxford University Press,, 275.

Jordan j, Mullen M, \& Murmighan JK. (2011).Striving for the Moral Self: The Effects of Recalling Past Moral Actions on Future Moral Behavior.Personality and Social Psychology Bulletin, 37 (5), 701-713

Jowkar B, \& Haghnegahdar M. (1395), relationship between moral identity and academic dishonesty: investigating moderator role of gender. Learning and Instruction Studies, 8 (2),143-162 (In Persian).

Juhl J, Routledge C, Arndt J, Sedikides C, \& Wildschut T. (2010). Fighting the future with the past: Nostalgia buffers existential threat. Joumal of Research in Personality, 44(1),309-314.

King P, \& Furrow J. (2004). Religion as a Resource for Positive Youth Development: Religion, Social Capital, and Moral Outcomes. Developmental psychology, 40 (5). 703-713.

Kochanska G. (2002). Committed Compliance, Moral Self, and Internalization: A Mediational

$$
\begin{aligned}
& \text { بر مبناى نتايج فوق، مىتوان در برنامهى درسى و } \\
& \text { كفتمانهاى تربيت اخلاقى جايى براى نوستالثى گرايى و } \\
& \text { تسهيل تجربيات نوستالزيكك در نظر گرفت. }
\end{aligned}
$$

$$
\begin{aligned}
& \text { سياسگزارى } \\
& \text { از دانشجويان مشاركت كننده در تحقيق و ادارهى } \\
& \text { خوابگاههاى دانشگاه شيراز قدردانى مى گردد. }
\end{aligned}
$$

\section{References}

Ahmadi E. (2017). Comparing ethical self-superiority in the fields of doing ethical behaviors and not doing unethical behaviors. Quarterly Research Psychological Applied, 8(1),121-132.

Aristotle (2011).Nichomachean Ethics (translated by M.H.Lotfi). Tehran, new design publication.

Batcho KI. (1995). Nostalgia: A psychological perspective. Perceptual and Motor Skills, 80(1), 131-143.

Batcho KI. (2013a). Nostalgia: The bittersweet history of a psychological concept. History of Psychology, 16(1), 165-176.

Blasi A. (1995). Moral understanding and the moral personality: The process of moral integration. IN: M. Kurtines \& J. L. Gewirtz Editors. Moral development: An introduction. Boston, MA, 229-253.

Blasi A. (2004). Moral functioning: Moral understanding and personality. Moral development, self, and identity, 335-348.

Cheung WY, Sedikides C, \& Wildschut T. (2016). Induced nostalgia increases optimism (via social connectedness and self-esteem) among individuals high, but not low, in trait nostalgia. Personality and Individual Differences, 90(1), 283-288.

Etemaad J, Jowkar B, Dabbagh H, Kojuri J, \& Roosta S. (2018). The Effect of Evoking Nostalgic Memories on the Homeostatic Variables (Mental and Physical) Among Cardiovascular Patients. Advances in Cognitive Sceince, 19(4), 57-69. 
Model. Developmental psychology, 38 (3). 339-351.

Li Y. (2015) Nostalgia Promoting Pro-Social Behavior and Its Psychological Mechanism. Open Journal of Social Sciences, 3 (1), 177-186

Routledge C, Amdt J, Wildschut T, Sedikides C, Hart C, Juhl J. (2011). The past makes the present meaningful: Nostalgia as an existential resource. Joumal of Personality and Social Psychology, 101(3), 638-652.

Routledge C, Sedikides C, Wildschut T, \& Juhl J. (2013). Finding meaning in the past: Nostalgia as an existential resource. IN: K. Markman, T. Proulx, \& M. Lindberg Editors. The psychology of meaning. Washington, DC: American Psychological Association, 297316.

Sedikides C, Wildschut T, Amdt J, \& Routledge CD. (2006). Affect and the self. IN: J. P. Forgas Editors. Affect in social thinking and behavior: Frontiers in social psychology New York, NY: Psychology Press, 197-215.

Sedikides C, Wildschut T, Routledge C, Amdt J, Hepper E, \& Zhou X. (2015). To Nostalgize: Mixing Memory with Affect and Desire. Advances in Experimental Social Psychology, 51 (1), 179-281.

Sedikides C, Wildschut, T, Gaertner L, Routledge C, \& Arndt J. (2008). Nostalgia as enabler of self continuity. IN: F. Sani Editors. Self continuity:
Individual and collective perspectives. New York, NY, US: Psychology Press, 227-239.

Tepe R, Zhong ChB, \& Inzlicht M.(2015).How Emotions Shape Moral Behavior. Some Answers (and Questions) for the Field of Moral Psychology. Social and Personality Psychology Compass, 9(1), 1-14.

Van Dijke M, Wildschut T, Leunissen J, \& Sedikides C. (2015). Nostalgia buffers the negative impact of low procedural injustice on cooperation. Organizational Behavior and Human Decision Processes, 127(1), 15-29.

Van Tilburg WAP, Igou, ER, \& Sedikides C. (2013). In search of meaningfulness: Nostalgia as an antidote to boredom. Emotion, 13 (3), 450461.

Walker L J, \& Frimer JA. (2007). Moral personality of brave and caring exemplars. Journal of Personality and Social Psychology, 93 (5), 845-860.

Wildschut T, Sedikides C, Amdt J, \& Routledge C. (2006). Nostalgia: Content, triggers, functions. Joumal of Personality and Social Psychology, 91(5), 975-993.

Zagzebski LT. (2004). Divine Motivation Theory, Cambridge :Cambridge University Press.

Zhou X, Wildschut T, Sedikides C, Chen X, \& Vingerhoets MJ. (2012). Heartwarming Memories: Nostalgia Maintains Physiological Comfort. Emotion, 12(4), 678-684. 